\title{
PENGARUH PERLAKUAN AWAL TERHADAP KARAKTERISTIK KIMIA, MIKROBIOLOGI, DAN ORGANOLEPTIK TEPUNG ONCOM MERAH
}

\author{
Alsuhendra ${ }^{1)}$ dan Ridawati ${ }^{2)}$ \\ ${ }^{1,2}$ Program Studi Pendidikan Vokasional Seni Kuliner, Fakultas Teknik, Universitas Negeri Jakarta \\ ${ }^{1,2}$ Kampus A UNJ J1. Rawamangun Muka Jakarta 13320 \\ E-mail : alsuhendra@gmail.com ${ }^{1)}$, ridawati.sesil@gmail.com ${ }^{2)}$
}

\begin{abstract}
ABSTRAK
Penelitian ini bertujuan untuk mempelajari pengaruh perlakuan awal terhadap karakteristik kimia, mikrobiologi, dan organoleptik tepung oncom merah. Penelitian dilaksanakan dengan menggunakan 3 jenis perlakuan, yaitu oncom merah segar langsung dikeringkan tanpa mendapatkan perlakuan apapun (P0), oncom merah segar dikukus terlebih dahulu, lalu dikeringkan (P1), dan oncom merah segar dipisahkan miselium dan spora kapangnya terlebih dahulu, lalu dikukus dan dikeringkan (P2). Hasil penelitian menunjukkan bahwa rendemen tepung oncom merah yang diperoleh dari ketiga perlakuan berkisar antara 32,39 - 35,57\%. Tidak ada pengaruh perlakuan terhadap rendemen tepung oncom merah $(\alpha=0.05)$. Kadar air, abu, dan lemak tepung oncom merah dari ketiga perlakuan juga tidak berbeda nyata, tetapi perlakuan memberikan pengaruh nyata terhadap kadar protein dan karbohidrat tepung $(\alpha=0.05)$. Secara mikrobiologis, angka lempeng total (ALT) tepung oncom merah dari ketiga perlakuan berturut-turut adalah 2,05 x $10^{6} \mathrm{CFU}(\mathrm{P} 0), 2,49 \mathrm{x} 10^{4} \mathrm{CFU}(\mathrm{P} 1)$ dan $1,95 \times 10^{3} \mathrm{CFU}(\mathrm{P} 2)$. Tepung oncom merah P0 dinilai oleh sebagian besar panelis memiliki warna cokelat gelap, aroma oncom kuat, rasa tepung kedelai mentah dengan sedikit pahit, dan tekstur halus dan agak halus. Tepung oncom merah P1 memiliki warna coklat gelap, aroma oncom agak kuat, agak terasa tepung kedelai mentah dan agak pahit, dan tekstur halus. Sementara itu, tepung oncom merah P2 memiliki warna agak coklat, aroma oncom agak kuat, tidak terrasa tepung kedelai dan agak sedikit pahit, dan tekstur halus.
\end{abstract}

Kata Kunci: perlakuan awal, tepung, oncom merah, karakteristik kimia, organoleptik

\section{PENDAHULUAN}

Oncom merupakan salah satu produk olahan fermentasi yang berasal dari daerah Jawa Barat. Melalui proses fermentasi, oncom memiliki aroma dan cita rasa yang khas karena terjadi peruraian struktur kimia bahanbahan bersifat kompleks menjadi senyawa-senyawa yang lebih sederhana dan mudah dicerna dan diserap oleh tubuh (Zamakhsyari dkk., 2018).

Meskipun memiliki harga relatif murah, oncom mengandung gizi tinggi (Suryadi, 2016). Oncom juga mengandung senyawa fungsional yang bermanfaat bagi kesehatan, yaitu karotenoid yang dihasilkan oleh kapang Neurospora sp (Purnamasari dkk., 2013).

Masyarakat telah memanfaatkan oncom sebagai bahan makanan pendamping nasi atau sebagai makanan camilan. Beberapa contoh olahan oncom yang banyak dijumpai di masyarakat adalah tumis oncom, pepes oncom, oncom goreng, dan comro.

Oncom dibuat dari bahan yang berharga murah karena berasal dari limbah pengolahan produk pangan, seperti limbah pembuatan tahu. Berbeda dengan produk fermentasi lainnya yang telah dibuat dengan proses modern menggunakan inokulum, pembuatan oncom di Indonesia masih dilakukan dengan cara tradisional tanpa menggunakan inokulum, sehingga kualitas oncom menjadi tidak stabil (Sastraatmadja dkk., 2002).
Walaupun banyak dikonsumsi masyarakat, pengembangan produk oncom di wilayah luar pulau Jawa masih jauh tertinggal jika dibandingkan dengan produk fermentasi lainnya, seperti tempe, kecap dan terasi. Hal ini kemungkinan disebabkan oleh masih terbatasnya produsen yang memproduksi oncom serta sulitnya oncom diperoleh di wilayah luar pulau Jawa.

Jenis oncom yang dikenal di masyarakat ada dua, yaitu oncom merah dan oncom hitam. Hal yang membedakan di antara kedua jenis oncom adalah jenis kapang dan bahan baku yang digunakan (Suryadi, 2016). Oncom merah dibuat dari ampas tahu dan difermentasi oleh kapang Neurospora sitophila. Kapang Neurospora $s p$ merupakan kapang yang umum ditemukan pada oncom merah karena memiliki pertumbuhan yang cepat untuk membentuk warna kuning (Purnamasari dkk., 2013). Sementara itu, oncom hitam dibuat dari bungkil kacang tanah dan difermentasi oleh kapang Rhizophus oligosporus. Spora yang dihasilkan berwarna hitam (Sofyan, 2003).

Oncom termasuk jenis bahan pangan yang mudah rusak akibat perubahan secara fisik, kimia, enzimatis, atau mikrobiologis. Oncom segar hanya memiliki umur simpan sekitar 1-2 hari pada suhu ruang.

Berbagai upaya perlu dilakukan untuk meningkatkan umur simpan oncom agar oncom dapat dikonsumsi oleh masyarakat sepanjang waktu. Pada tahun 2018 telah 
dilaporkan proses pembuatan oncom merah instan dengan perlakuan awal pemanasan basah pada oncom merah sebelum dilakukan instanisasi (Zamakhsyari dkk., 2018). Dari penelitian tersebut diketahui bahwa oncom instan yang dihasilkan dapat diterima oleh panelis.

Pada penelitian ini telah dilakukan pembuatan tepung oncom merah sebagai produk semiolah oncom yang memiliki umur simpan panjang. Oncom yang digunakan sebagai bahan baku adalah oncom merah.

Sebagaimana produk tepung lainnya, tepung oncom adalah bentuk hasil pengolahan bahan kering dari oncom dengan cara pengilingan atau penepungan. Dengan kandungan air yang rendah, tepung oncom diharapkan memiliki umur simpan yang lebih panjang daripada oncom segar.

Untuk mendapatkan tepung oncom dengan kualitas baik, maka proses pembuatan tepung oncom didahului oleh perlakuan awal pada oncom segar. Terdapat 3 jenis perlakuan awal yang diberikan pada oncom sebelum dijadikan tepung, yaitu oncom merah segar langsung dikeringkan dengan oven tanpa mendapatkan perlakuan apapun, oncom merah segar dikukus terlebih dahulu, lalu dikeringkan dengan oven, dan oncom merah segar dipisahkan miselium dan spora kapangnya terlebih dahulu, lalu dikukus dan dikeringkan dengan oven. Melalui penelitian ini dapat diketahui karakteristik kimia, mikrobiologi, dan organoleptik dari tepung oncom merah yang dihasilkan.

\section{RUANG LINGKUP}

Ruang lingkup dari penelitian ini dijelaskan di bawah ini:

1. Permasalahan yang dipelajari pada penelitian ini adalah pendeknya umur simpan oncom merah segar, sehingga perlu dicari upaya untuk meningkatkan umur simpan tersebut dengan cara mengolah oncom merah segar menjadi produk semiolah, yaitu tepung oncom merah.

2. Penelitian ini dilakukan pada oncom merah dengan 3 jenis perlakuan awal sebelum dijadikan tepung, yaitu oncom merah segar yang langsung dikeringkan (kontrol), oncom merah segar dikukus terlebih dahulu sebelum dikeringkan, dan oncom merah segar yang dibuang spora kapangnya sebelum dikeringkan.

3. Rencana hasil yang didapatkan dari penelitian ini adalah produk semiolah tepung oncom merah yang memiliki karakteristik kimia, mikrobiologis, dan organoleptik yang baik, sehingga dapat diaplikasikan pada berbagai jenis olahan oncom dengan sifat yang mirip dengan oncom segar.

\section{BAHAN DAN METODE}

Oncom merah yang digunakan pada penelitian ini adalah oncom merah segar yang diperoleh dari Pasar Rawamangun Jakarta Timur. Beberapa bahan lain diperlukan pula dalam penelitian ini adalah bahan untuk analisis sifat kimia, organoleptik, dan mikrobiologi tepung oncom, seperti media Potato Dextrose Agar, Nutrient Broth, safranin, dan spiritus.

Penelitian ini dilakukan dalam 5 tahap, sebagaimana dijelaskan di bawah ini.

1. Persiapan Bahan Baku

Oncom merah yang digunakan pada penelitian ini berukuran 15 x $8 \mathrm{~cm}$. Sebanyak $500 \mathrm{~g}$ oncom merah dipotong kecil berbentuk dadu, lalu dimasukkan ke dalam wadah plastik HDPE bertutup yang steril. Bahan ini disimpan dalam lemari es suhu $4^{\circ} \mathrm{C}$ sampai siap untuk digunakan.

2. Pembuatan Tepung Oncom Merah

Proses pembuatan tepung oncom dilakukan mengikuti beberapa tahap berikut:

1) Pemilihan bahan

Oncom dipilih yang berwarna merah dengan keadaan fisik baik, yaitu memiliki volume padat dengan bentuk kotak, spora yang menempel pada oncom tersebar merata, serta memiliki aroma khas oncom, yaitu aroma kedelai yang telah difermentasi.

2) Perlakuan awal

Oncom yang telah dipotong dadu selanjutnya diberi 3 jenis perlakuan awal, yaitu oncom merah segar (tanpa perlakuan), oncom merah segar dikukus selama 10 menit sebelum dikeringkan, dan oncom merah segar dipisahkan miselium dan spora kapangnya, kemudian dikukus selama 10 menit.

3) Penghancuran

Setelah diberi perlakuan awal, oncom merah dihancurkan dengan menggunakan tangan hingga diperoleh hancuran kasar. Penghancuran dilakukan agar proses pengeringan oncom berlangsung dengan cepat.

4) Pengeringan

Hancuran oncom merah dikeringkan dalam oven pada suhu $120^{\circ} \mathrm{C}$ selama 3,5 jam.

5) Penggilingan

Oncom merah yang telah kering digiling menjadi tepung menggunakan food processor.

6) Pengayakan

Oncom yang telah dihaluskan kemudian diayak menggunakan ayakan berukuran 100 mesh.

7) Penyimpanan

Tepung oncom selanjutnya disimpan di tempat kering dalam botol kaca yang sudah disterilisasi.

\section{Analisis Karakteristik Kimia Tepung Oncom Merah}

Tepung oncom yang diperoleh pada tahap sebelumnya dipelajari karakteristik kimianya yang meliputi kadar air, abu, lemak, protein, dan karbohidrat. Kadar air dianalisis dengan metode pengeringan menggunakan oven listrik pada suhu $105^{\circ} \mathrm{C}$, sedangkan kadar abu dianalisis dengan cara pengabuan kering menggunakan tanur dengan suhu $500-600^{\circ} \mathrm{C}$ selama 6 jam. Sementara itu, kadar lemak ditentukan dengan metode Soxhlet dan kadar protein ditentukan dengan 
metode mikro Kjeldhal. Kadar karbohidrat ditentukan dengan metode by difference (Yenrina, 2015).

\section{Analisis Karakteristik Mikrobiologi Tepung Oncom Merah \\ Karakteristik mikrobiologi tepung oncom yang} diamati pada penelitian ini adalah angka lempeng total (ALT) atau Total Plate Count (TPC). Penentuan ALT dapat digunakan sebagai indikator kecukupan proses pengolahan, higiene sanitasi produk, analisis mikroba lingkungan produk, proses pengawasan mutu, dan sebagai dasar kecurigaan dapat atau tidak diterimanya suatu produk berdasarkan kualitas mikrobiologinya (Puspandari dan Isnawati, 2015).

5. Analisis Karakteristik Organoleptik Tepung Oncom Merah

Uji organoleptik dilakukan oleh 10 orang panelis terlatih menggunakan metode qualitatif descriptive analysis (QDA) terhadap 4 atribut tepung oncom, yaitu warna, aroma, rasa, dan tekstur. Uji ini ditujukan untuk mendapatkan gambaran karakteristik dan intensitas mutu dari tepung oncom merah. Data dari hasil uji QDA disajikan dalam bentuk grafik jaring laba-laba (spider web) dan diuraikan secara deskriptif (Kusumaningrum dkk., 2014).

\section{PEMBAHASAN}

Pembuatan tepung oncom merah menggunakan 3 jenis perlakuan awal berbeda telah menghasilkan tepung oncom dengan rendemen berbeda pula. Pada Tabel 1 dapat dilihat bahwa rendemen untuk untuk tepung dengan perlakuan P0 dalah 35,57\%, tepung P1 sebesar $32,39 \%$, dan $32,44 \%$ untuk P0. Berdasarkan nilai tersebut dapat dinyatakan bahwa perlakuan pembuangan miselium dan spora oncom sebelum proses pengeringan tidak menurunkan jumlah tepung yang dihasilkan, sehingga nilai rendemen dari tepung tidak berbeda dengan tepung oncom dengan perlakuan lainnya.

Tabel 1. Rendemen Tepung Oncom Merah

\begin{tabular}{|c|l|c|}
\hline No & Perlakuan & Rendemen (\%) \\
\hline 1 & P0 & $35,57 \pm 1,14^{\mathrm{a}}$ \\
\hline 2 & P1 & $32,39 \pm 1,52^{\mathrm{a}}$ \\
\hline 3 & P2 & $32,44 \pm 3,00^{\mathrm{a}}$ \\
\hline
\end{tabular}

1. Karakteristik Kimia Tepung Oncom

Tepung oncom merah yang diperoleh telah dipelajari karakteristik kimianya dengan melakukan analisis kadar air, abu, lemak, protein, dan karbohidrat. Karakteristik kimia tepung oncom merah tersebut dapat dilihat pada Tabel 2.
Kadar Air. Sebagaimana produk tepung-tepungan lainnya, kadar air tepung oncom merah termasuk rendah. Tabel 2 memperlihatkan kadar air tepung oncom merah berkisar antara 6,87-7,53 g/100 g. Kadar air tersebut hampir sama dengan kadar air tepung kedelai, yaitu 6,71 g/100 g (Astawan dan Hazmi, 2016).

Tabel 2. Karakteristik Kimia Tepung Oncom Merah (g/per 100 g)

\begin{tabular}{|c|l|c|c|c|}
\hline \multirow{2}{*}{ No } & \multicolumn{2}{|c|}{ Karakteristik } & \multicolumn{3}{|c|}{ Kandungan } \\
\cline { 3 - 5 } & & P0 & P1 & P2 \\
\hline 1 & Air & $6,87 \pm 0,22^{\mathrm{a}}$ & $7,53 \pm 0,35^{\mathrm{a}}$ & $6,91 \pm 0,35^{\mathrm{a}}$ \\
\hline 2 & Abu & $1,91 \pm 0,03^{\mathrm{a}}$ & $1,91 \pm 0,04^{\mathrm{a}}$ & $1,88 \pm 0,03^{\mathrm{a}}$ \\
\hline 3 & Lemak & $11,34 \pm 0,44^{\mathrm{a}}$ & $11,68 \pm 0,13^{\mathrm{a}}$ & $10,18 \pm 0,28^{\mathrm{a}}$ \\
\hline 4 & Protein & $20,98 \pm 0,86^{\mathrm{a}}$ & $22,02 \pm 0,33^{\mathrm{a}}$ & $16,13 \pm 0,13^{\mathrm{b}}$ \\
\hline 5 & Karbohidrat & $58,91 \pm 0,02^{\mathrm{a}}$ & $56,86 \pm 0,15^{\mathrm{a}}$ & $64,91 \pm 0,25^{\mathrm{b}}$ \\
\hline
\end{tabular}

Keterangan: angka-angka pada baris sama yang diikuti oleh huruf yang sama menunjukkan hasil tidak berbeda nyata pada $\alpha=0,05$

Kadar air tepung oncom merah yang diperoleh termasuk rendah. Rendahnya kadar air tepung disebabkan oleh proses pengeringan ketiga jenis oncom merah dalam oven dengan suhu $120^{\circ} \mathrm{c}$ selama $3,5 \mathrm{jam}$. Hasil analisis ragam menunjukkan tidak terdapat pengaruh perlakuan terhadap kadar air ketiga jenis tepung oncom $(\alpha=0.05)$. Ini menunjukkan bahwa tepung oncom merah yang dibuat dari oncom yang dikukus dengan atau tanpa dibuang miselium dan sporanya terlebih dahulu memiliki kadar air yang tidak berbeda dengan tepung oncom yang dibuat dari oncom merah segar. Kadar air tepung oncom yang rendah memberikan keuntungan karena dapat memperpanjang umur simpan tepung.

Kadar Abu. Kadar abu menunjukkan menunjukkan campuran dari komponen anorganik atau mineral yang 
terdapat dalam suatu bahan pangan. Penentuan kadar abu dijadikan sebagai cara untuk menduga kandungan mineral bahan pangan secara kasar.

Pada Tabel 2 dapat diketahui bahwa seluruh tepung oncom merah memiliki kadar abu yang hampir sama, yaitu 1,91 g/100 g untuk P0 dan P1 serta 1,88 g/100 g untuk P2. Kadar abu ini juga hampir sama dengan kadar abu tepung kedelai $(1,99 \mathrm{~g} / 100 \mathrm{~g})$ (Astawan dan Hazmi, 2016). Tidak terdapat perbedaan nyata pada kadar abu tepung oncom merah yang mendapat perlakuan awal berbeda $(\alpha=0.05)$.

Kadar Lemak. Kadar lemak 3 jenis tepung oncom merah lebih tinggi jika dibandingkan dengan kadar lemak oncom segar. Jika kadar lemak oncom segar adalah $6 \mathrm{~g} / 100 \mathrm{~g}$, maka dari Tabel 2 dapat dilihat bahwa kadar lemak ketiga jenis tepung oncom merah adalah $11,34 \mathrm{~g} / 100 \mathrm{~g}$ (P0), 11,68 g/100 g (P1), dan 10,18 g/100 g (P2). Namun, kadar lemak tepung oncom merah lebih rendah daripada tepung kedelai $(38,65 \mathrm{~g} / 100 \mathrm{~g})$, yaitu bahan dasar pembuatan oncom (Astawan dan Hazmi, 2016). Perlakuan awal pada oncom merah ternyata tidak memberikan pengaruh nyata terhadap kadar lemak tepung oncom merah $(\alpha=0.05)$.

Kadar Protein. Kadar protein tepung oncom merah lebih tinggi daripada kadar protein oncom. Hal ini disebabkan oleh rendahnya kadar air tepung oncom, sehingga terjadi pemekatan kadar protein.

Pada Tabel 2 dapat diketahui bahwa tepung oncom merah P2 memiliki kadar protein yang paling rendah dibandingkan dengan tepung oncom merah P0 dan P1. Hal tersebut diduga disebabkan oleh adanya pembuangan miselium dan spora kapang pada oncom merah sebelum oncom dikeringkan. Miselium dan spora kapang terdiri dari sel-sel yang disusun oleh protein, sehingga pembuangan miselium dan spora kapang Neurospora sitophila akan menurunkan kadar protein tepung oncom.

Kadar Karbohidrat. Kadar karbohidrat tepung oncom merah dihitung dengan metode by difference. Perbedaan kadar protein dari ketiga jenis tepung memengaruhi kadar karbohidrat tepung oncom. Tepung oncom merah dengan perlakuan P2 memiliki kadar karbohidrat yang paling tinggi dibandingkan dengan tepung oncom P0 dan P1.

Pembuangan miselium dan sporan oncom sebelum dilakukan pengeringan dalam pembuatan tepung oncom merah (P2) menyebabkan menurunnya kadar protein tepung oncom. Sebagai akibatnya, proporsi kadar karbohidrat tepung oncom terhadap kadar zat gizi lainnya menjadi meningkat. Ini berarti bahwa pembuangan miselium dan spora kapang oncom berpengaruh nyata terhadap kadar karbohidrat tepung oncom.

\section{Karakteristik Mikrobiologis Tepung Oncom}

Karakteristik mikrobiologis tepung oncom merah yang dipelajari pada penelitian ini adalah jumlah koloni kapang atau Angka Lempeng Total (ALT) koloni kapang. Nilai ALT yang diperoleh selanjutnya dibandingkan dengan syarat mutu tepung menurut SNI 3788:2009. Tabel 3 menyajikan nilai ALT untuk ketiga jenis tepung yang dibuat.

Tabel 3. Nilai Angka Lempeng Total Tepung Oncom Merah

\begin{tabular}{|c|l|c|}
\hline No & Perlakuan & ALT (CFU) \\
\hline 1 & P0 & $2,05 \pm 0,49 \times 10^{6 \mathrm{a}}$ \\
\hline 2 & P1 & $2,45 \pm 0,49 \times 10^{4 \mathrm{~b}}$ \\
\hline 3 & P2 & $1,95 \pm 0,21 \times 10^{3 \mathrm{c}}$ \\
\hline
\end{tabular}

Keterangan: angka-angka pada kolom sama yang diikuti oleh huruf yang sama menunjukkan hasil tidak berbeda nyata pada $\alpha=0,05$

Pembuatan tepung oncom merah dengan cara pengukusan sebelum dikeringkan, baik dengan atau tanpa pembuangan miselium dan spora kapang dapat menurunkan nilai ALT tepung oncom. Tepung oncom merah yang dibuat dari oncom segar tanpa perlakuan awal (kontrol/P0) memiliki nilai ALT paling tinggi, yaitu $2,05 \times 10^{6}$ CFU. Nilai ini lebih tinggi daripada batas maksimum ALT pada tepung-tepungan menurut SNI 3788:2009 ( 1 x $\left.10^{6} \mathrm{CFU}\right)$. Ketiga perlakuan awal pada oncom sebelum dijadikan tepung oncom merah memberikan pengaruh nyata terhadap nilai ALT $(\mathrm{p}<0,05)$.

Perbedaan nilai ALT pada produk tepung oncom merah dapat disebabkan oleh adanya perbedaan faktorfaktor yang mendukung pertumbuhan kapang pada tepung tersebut. Faktor-faktor yang mempengaruhi kerusakan pangan oleh mikroba adalah kadar $\mathrm{pH}$, ketersediaan nutrisi, air, oksigen, dan senyawa penghambat bakteri (Chrismanuel dkk., 2012). Tepung oncom memiliki kandungan makanan berupa protein, karbohidrat, dan lemak yang diperlukan oleh kapang untuk pertumbuhannya, sehingga tepung oncom yang tidak disimpan dengan baik maka dapat ditumbuhi kembali oleh kapang. Tepung oncom yang disimpan di tempat yang lembab akan mendukung pertumbuhan kapang.

3. Karakteristik Organoleptik Tepung Oncom

Oncom merupakan produk olahan fermentasi dari ampas tahu. Dengan adanya proses fermentasi terhadap 
protein, lemak, dan karbohidrat yang terdapat didalam ampas tahu, terjadi perubahan sifat mutu pada rasa, aroma, warna dan tekstur. Proses pengeringan yang dilakukan terhadap oncom merah juga sangat berpengaruh terhadap sifat mutu tepung oncom. Perubahan yang terjadi mengikuti setiap proses pengolahan dikarenakan terdapatnya kandungan zat gizi seperti karbohidrat, protein dan lemak.

Pada penelitian ini telah dipelajari penilaian panelis terhadap karakteristik warna, aroma, rasa, dan tekstur tepung oncom merah. Melalui uji qualitatif descriptive analysis (QDA), hasil penilaian panelis dapat dijelaskan dengan menggunakan grafik di bawah ini.

Warna. Warna merupakan salah satu parameter fisik tepung oncom merah yang penting untuk dipelajari. Warna seringkali dianggap sebagai faktor pertama yang menentukan kesukaan konsumen dibandingkan dengan aspek sensori lainnya, seperti rasa dan aroma.

Warna bahan makanan dapat disebabkan oleh beberapa sumber, salah satu yang terpenting di antaranya disebabkan oleh pigmen alami yang terdapat dalam bahan tersebut. Pada oncom merah, warna merah (atau oranye) disebabkan oleh spora yang dihasilkan oleh kapang Neurospora sitophila. Selain pigmen, warna pada bahan pangan juga disebabkan oleh reaksi pencoklatan akibat proses pemanasan gula, seperti reaksi Maillard antara gugus amino protein dengan gula pereduksi yang menghasilkan pigmen melanoidin yang berwarna coklat gelap (Martins dkk., 2001).

Hasil penilaian panelis terhadap warna tepung oncom merah disajikan pada Gambar 1. Menurut sebagian besar panelis $(60 \%)$, warna tepung oncom merah yang diolah tanpa perlakuan awal (P0) adalah cokelat gelap. Demikian juga dengan tepung oncom merah yang dikeringkan setelah dikukus dengan menggunakan miselium dan spora (P1), juga dinilai berwarna cokelat gelap oleh $70 \%$ panelis. Sementara itu, tepung oncom merah yang dikukus dengan memisahkan miselium dan spora kapang (P2) memiliki warna agak coklat menurut $60 \%$ panelis.

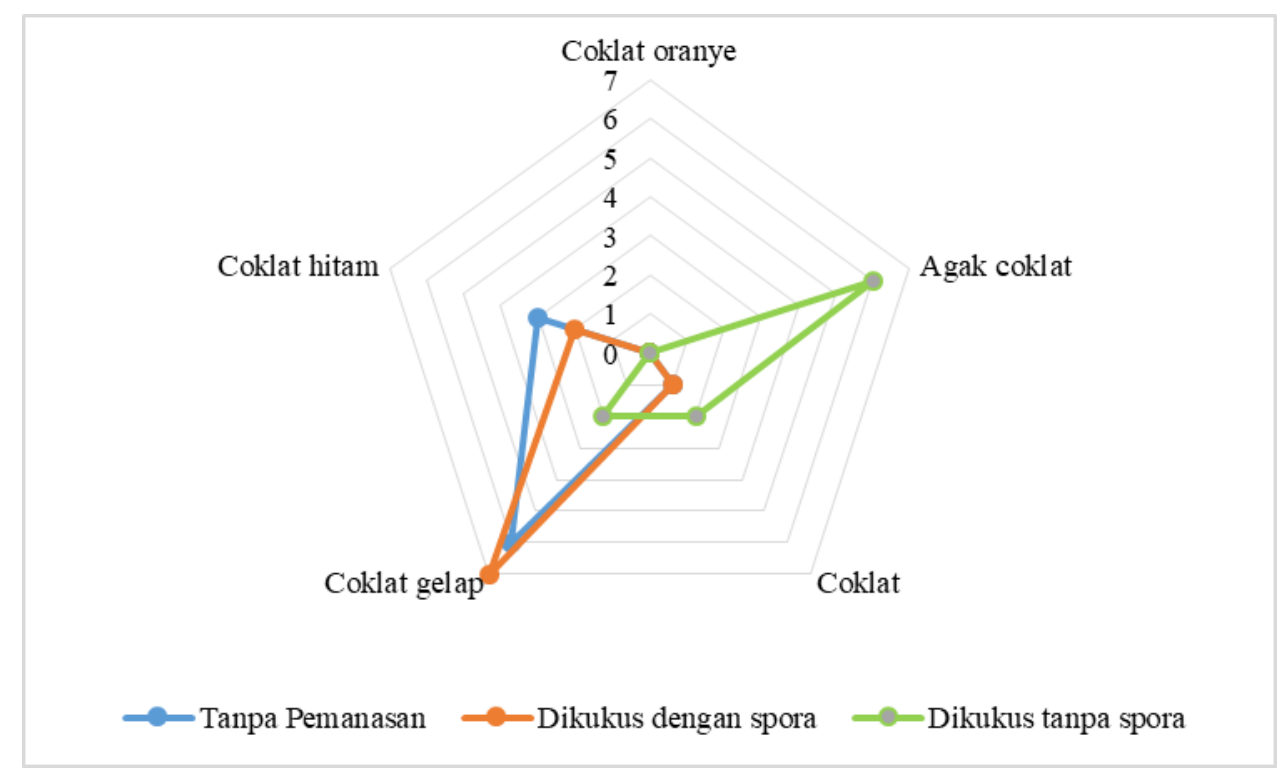

Gambar 1. Penilaian Warna Tepung Oncom Merah

Timbulnya warna cokelat gelap pada tepung oncom merah P0 dan P1 diduga disebabkan oleh banyaknya reaksi Maillard yang terjadi pada tepung tersebut jika dibandingkan dengan tepung oncom P2. Hal ini sejalan dengan tingginya kandungan protein pada tepung oncom P0 dan P1, sehingga memungkinkan semakin banyaknya senyawa melanoidin yang terbentuk selama proses pengeringan.

Aroma. Tepung oncom merah yang dikeringkan langsung tanpa pemanasan (P0) dinilai oleh $40 \%$ panelis sangat beraroma oncom dan menyengat, sedangkan sisanya (60\% panelis) menyatakan beraroma oncom kuat. Sementara itu, tepung oncom merah yang diproses dengan cara dikukus dan kemudian dikeringkan (P1) memiliki aroma oncom yang kuat menurut $40 \%$ dan beraroma oncom agak kuat menurut $60 \%$ panelis lainnya.

Pada Gambar 2 dapat dilihat bahwa tepung oncom merah yang diproses dengan cara dihilangkan miselium dan spora kapangnya, lalu dikukus dan dikeringkan (P2) dinilai memiliki aroma oncom agak kuat oleh $80 \%$ panelis. Hal ini memperlihatkan bahwa oncom segar yang langsung diolah menjadi tepung masih memiliki aroma oncom bahan asalnya. Namun, jika miselium dan spora oncom dibuang terlebih dahulu, maka aroma oncom pada tepung oncom menjadi semakin berkurang. 


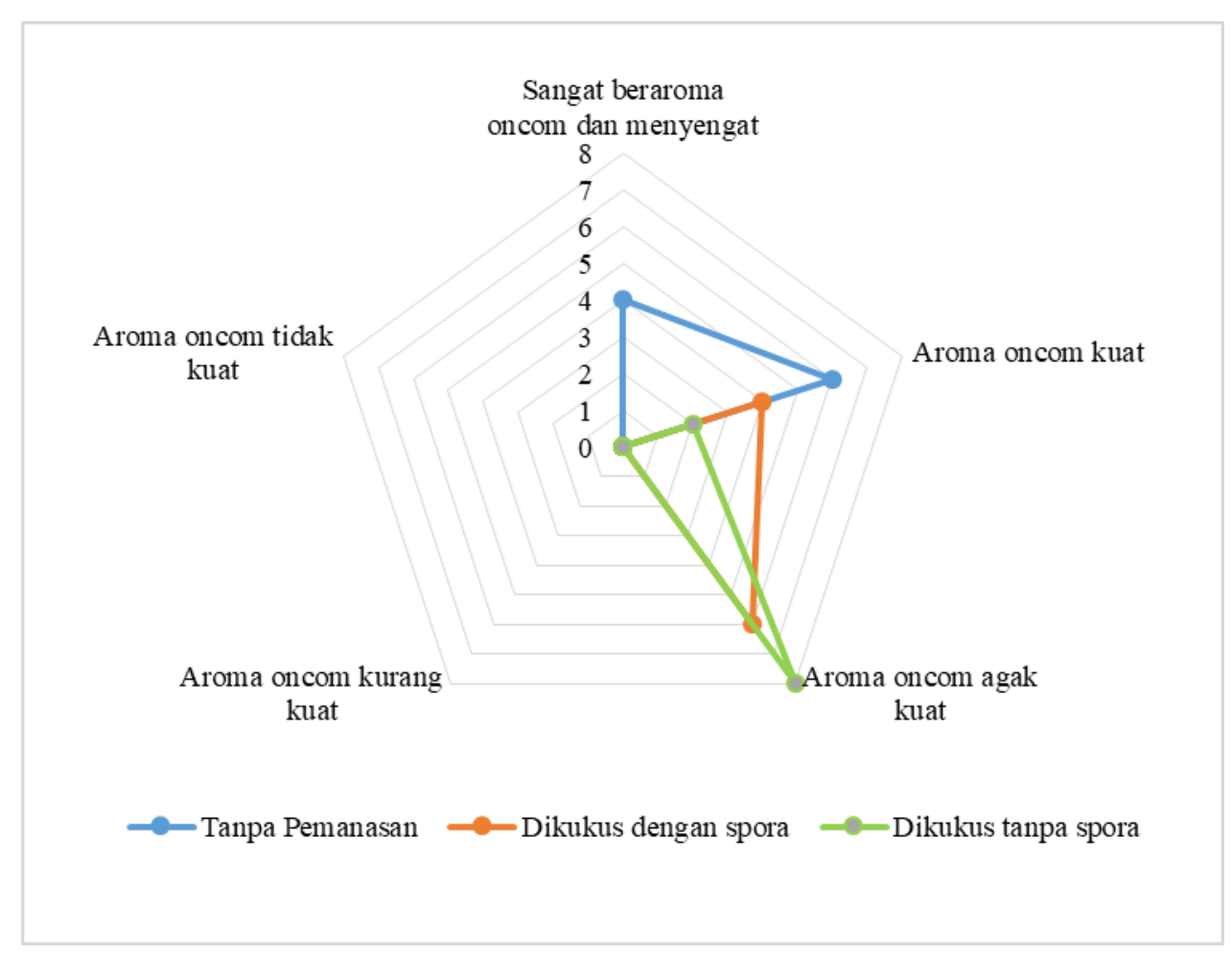

Gambar 2. Penilaian Aroma Tepung Oncom Merah

Rasa. Rasa menerangkan suatu kesan yang diterima melalui syaraf indera pengecap di lidah, sebagai hasil dari hadirnya senyawa-senyawa yang larut dalam air. Pada penelitian ini, penilaian rasa tepung oncom merah oleh panelis dilakukan dengan cara melarutkan tepung oncom merah ke dalam air, sehingga rasa dari tepung oncom merah dapat dideskripsikan lebih jelas. Karakteristik mutu tepung oncom merah yang dinilai oleh panelis adalah sangat terasa tepung kedelai mentah dan sedikit pahit, terasa tepung kedelai mentah dan sedikit pahit, agak terasa tepung kedelai mentah dan agak pahit, tidak terasa tepung kedelai dan agak pahit sedikit, sangat tidak terasa tepung kedelai dan tidak pahit yang digambarkan dalam bentuk grafik jaring laba-laba.
Hasil penelitian menunjukkan bahwa tepung oncom merah yang dikeringkan langsung tanpa pemanasan (P0) dinilai oleh semua panelis memiliki karakteristik terasa tepung kedelai mentah dan sedikit pahit, sedangkan tepung oncom merah yang diproses dengan cara dikukus dan kemudian dikeringkan (P1) dinilai oleh $60 \%$ panelis memiliki karakteristik agak terasa tepung kedelai mentah dan agak pahit serta $40 \%$ panelis menilai terasa tepung kedelai mentah dan sedikit pahit.

Berdasarkan Gambar 3 juga dapat diketahui bahwa tepung oncom merah yang diproses dengan cara dihilangkan miselium dan spora kapangnya (P2) memiliki karakteristik tidak terasa tepung kedelai dan agak sedikit pahit menurut $60 \%$ panelis. 


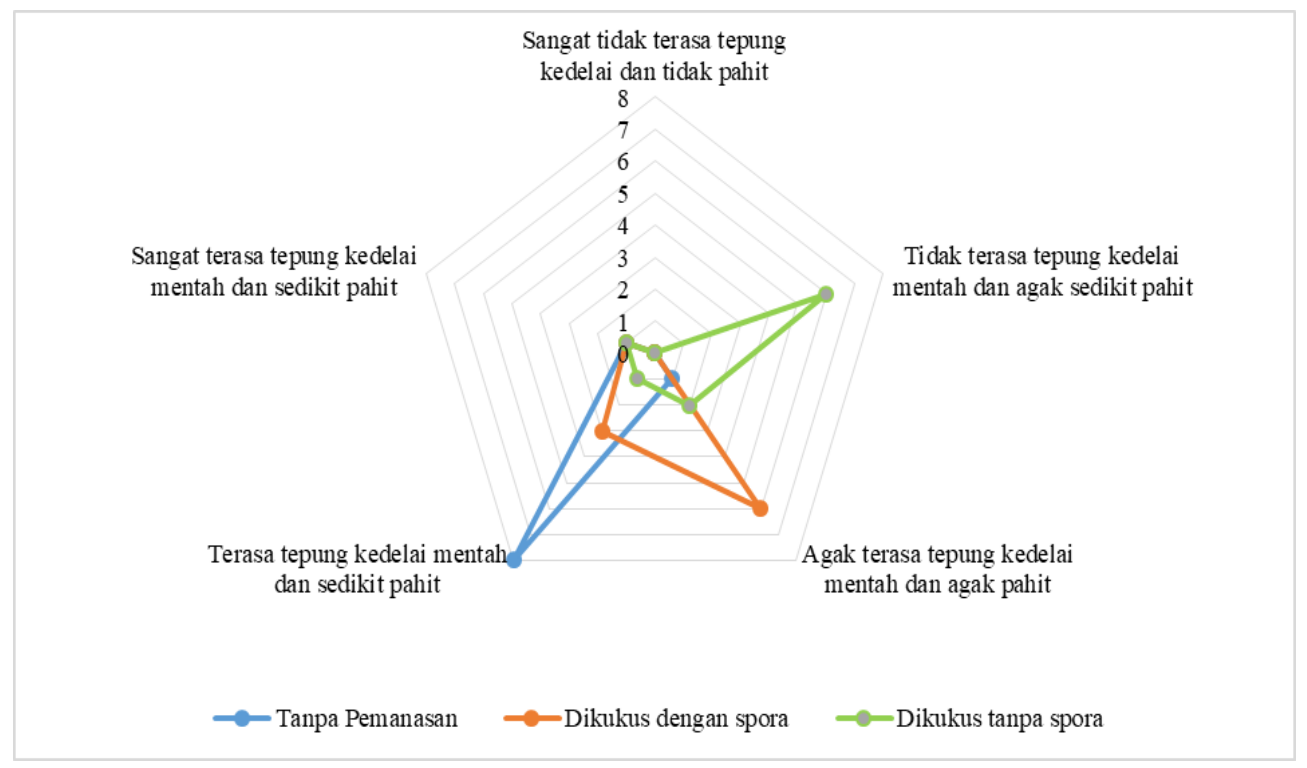

\section{Gambar 3. Penilaian Rasa Tepung Oncom Merah}

Tekstur. Pada penelitian ini, sebanyak 10 orang panelis menilai tekstur tepung oncom dengan menggunakan jari tangan. Karena itu, tekstur tepung oncom merah lebih menggambarkan kehalusan tepung ketika dipegang oleh jari tangan.

Hasil penilaian panelis, sebagaimana disajikan pada Gambar 4, memperlihatkan bahwa tepung P0, yaitu tepung oncom yang diolah tanpa perlakuan awal (kontrol), memiliki tekstur halus menurut $40 \%$ panelis, agak halus menurut $40 \%$ panelis, dan kurang halus menurut $20 \%$ panelis lainnya. Untuk tepung dengan perlakuan P1, sebanyak $20 \%$ panelis menilai tepung tersebut memiliki tekstur sangat halus, $60 \%$ menilai halus, dan sisanya $(20 \%)$ menilai agak halus. Sementara itu, tepung oncom merah P2 dinilai sangat halus oleh $10 \%$ panelis, halus oleh $70 \%$ panelis, dan agak halus oleh $20 \%$ panelis.

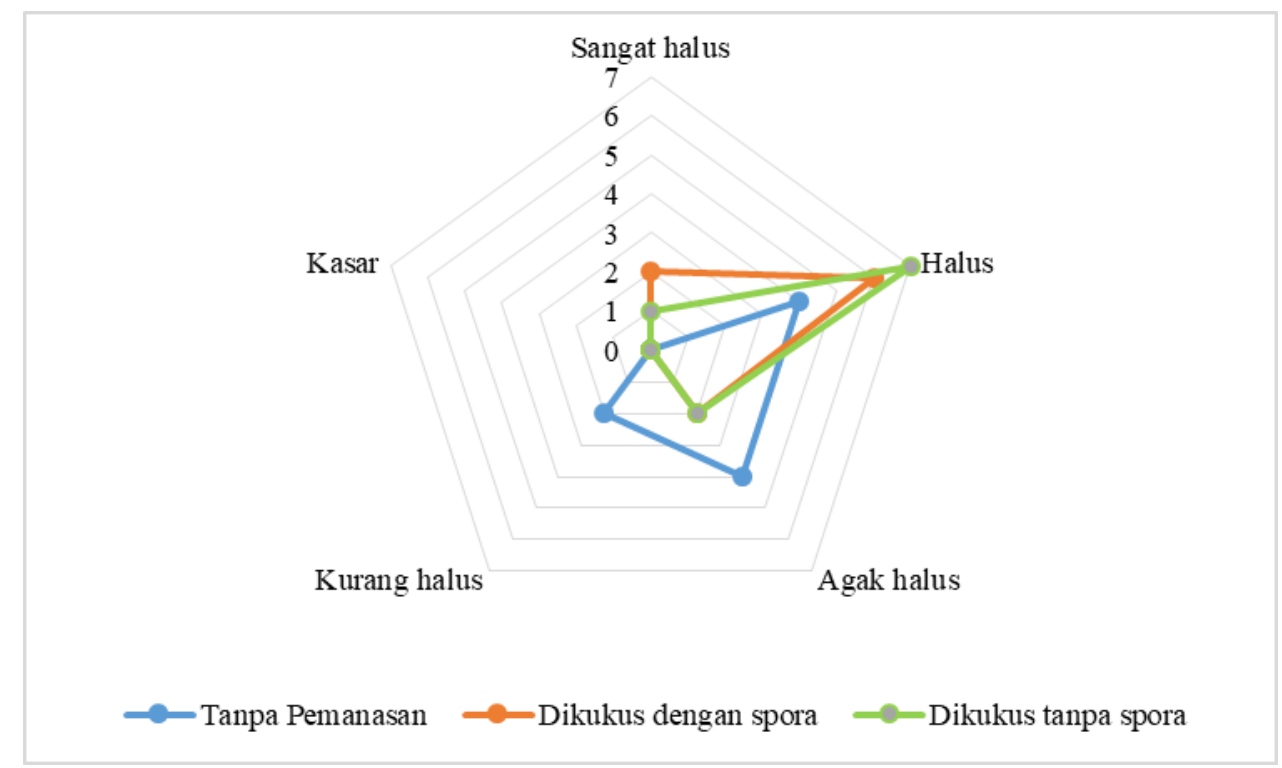

\section{Gambar 4. Penilaian Tekstur Tepung Oncom Merah}

\section{KESIMPULAN}

Berdasarkan penelitian yang dilakukan dapat diketahui rendemen tepung oncom merah berkisar antara $32,39-35,57 \%$. Tidak terdapat perbedaan nyata 3 jenis perlakuan awal pada oncom merah terhadap rendemen tepung oncom $(\alpha=0,05)$. Tepung oncom merah memiliki kandungan air yang rendah, sehingga diduga akan memiliki umur simpan yang panjang. Kandungan gizi 
tepung oncom merah cukup tinggi, khususnya protein. Perlakuan awal terhadap oncom merah memberikan pengaruh nyata terhadap kadar protein dan karbohidrat tepung oncom, tetapi tidak berpengaruh nyata terhadap kadar air, abu, dan lemak tepung $(\alpha=0,05)$.

Tepung oncom merah memiliki nilai ALT yang memenuhi syarat mutu tepung, khususnya tepung oncom merah P1 dan P2. Tiga jenis perlakuan awal pada oncom merah memberikan pengaruh nyata terhadap nilai ALT tepung $(\alpha=0,05)$. Secara organoleptik, tepung oncom merah P2 memiliki karakteristik organoleptik yang lebih baik daripada tepung P0 dan P1, yaitu berwarna agak coklat, aroma oncom agak kuat, tidak terasa tepung kedelai dan agak sedikit pahit, dan tekstur halus.

\section{SARAN}

Beberapa karakteristik fisik tepung oncom merah perlu dipelajari lebih lanjut agar proses pengemasan, distribusi, penyimpanan, dan pengolahan tepung oncom dapat dilakukan dengan tepat. Sebagai contoh, nilai densitas kamba dan densitas pemadatan tepung oncom penting diketahui karena erat kaitannya dengan pengemasan tepung, sedangkan nilai daya serap air, daya serap minyak, dan kelarutan tepung sangat diperlukan dalam rangka penerapan proses pengolahan lanjut yang cocok dilakukan terhadap tepung.

\section{DAFTAR PUSTAKA}

Astawan, M. dan K. Hazmi. 2016. Karakteristik fisikokimia tepung kecambah kedelai. Pangan. 25(2):105-112.

Chrismanuel, A., Y.B. Pramono, dan B. E. Setyani. 2012. Eefek pemanfaatan karaginan sebagai edible coating terhadap $\mathrm{pH}$, total mikroba dan $\mathrm{H} 2 \mathrm{~S}$ pada bakso selama penyimpanan 16 jam. Animal Agriculture Journal. 1(2):286-292.

Kusumaningrum, I., C.H. Wijaya, F. Kusnandar, A. Budi, dan T. Sari. 2014. Profil aroma dan mutu sensori citarasa pasta kakao unggulan dari beberapa daerah di Indonesia. J. Teknol. dan Industri Pangan. 25(1):107-108.

Martins, S.I.F.S., W.M.F. Jongen, dan M.A.J.S. Van Boekel. 2001. A review of Maillard reaction in food and implications to kinetic modelling. 11:364-373.

Purnamasari, N., M.A.M. Andriani, dan Kawiji. 2013. Pengaruh jenis pelarut dan variasi suhu pengering spray dryer terhadap kadar karotenoid kapang oncom merah (Neurospora sp.). Jurnal Teknosains Pangan. 2(1):108.

Puspandari, N. dan A. Isnawati. 2015. Deskripsi hasil uji angka lempeng total (ALT) pada beberapa susu formula bayi. Jurnal Kefarmasian Indonesia. 5(2):106-112.

Sastraatmadja, D.D., F. Tomita, dan Takanori Kasai. 2002. Production of high-quality oncom , a traditional indonesian fermented food, by the inoculation with selected mold strains in the form of pure culture and solid inoculum. J. Grad. Sch. Agr. Hokkaido Univ. 70(2):111-127.

Sofyan, H.M.I. 2003. Pengaruh suhu inkubasi dan konsentrasi inokulum Rhizopus oligosporus terhadap mutu oncom bungkil kacang tanah. INFOMATEK. 5(2):74.

Suryadi, A. 2016. Isolasi dan Karakterisasi Bakteri Lipolitik dari Oncom. Institut Pertanian Bogor.

Yenrina, R. 2015. Metode Analisis Bahan Pangan Dan Komponen Bioaktif. Padang: Andalas University Press.

Zamakhsyari, I., Alsuhendra, dan Ridawati. 2018. Pengaruh teknik pemanasan basah dalam pembuatan oncom instan terhadap kualitas tumis oncom. Jurnal Sains Boga. 1(1):18-22. 